\title{
Use of Zolpidem in Disorders of Consciousness Secondary to Autoimmune Encephalitis
}

\section{Merveen Appu*}

Valley Children's Healthcare, Pediatric Neurology, 9300 Valley Children's Place, Madera, California, USA

${ }^{*}$ Corresponding author: Merveen Appu, Pediatric Neurology, 9300 Valley Children's Place, Madera, California, USA, Tel: (559)353-6215; E-mail: MAppu@valleychildrens.org

Received date: November 01, 2017; Accepted date: November 18, 2017; Published date: November 28, 2017

Copyright: (c) 2017 Merveen A. This is an open-access article distributed under the terms of the Creative Commons Attribution License, which permits unrestricted use, distribution, and reproduction in any medium, provided the original author and source are credited.

Citation: Merveen A. Use Of Zolpidem in Disorders of Consciousness Secondary to Autoimmune Encephalitis. J Neuropsychiatry 2017, Vol. 1 No. 1: 2

\section{Editorial}

Autoimmune encephalitis is an increasingly identified area for practitioners in Neurology, Child Neurology and Psychiatry. The results of the California Encephalitis Project shed light on the importance of anti-NMDA receptor encephalitis as one more prevalent than infectious causes in younger cohort $(<18$ years) [1]. Since its first description in 2007, anti N-methyl Daspartate (NMDA) receptor encephalitis is an increasingly identified cause for autoimmune/paraneoplastic encephalitis [2]. Clinical features consist of a prodromal phase of infection (usually viral) associated with headaches, followed by an early phase characterized by psychosis, confusion, amnesia and dysphasia. We have reported hyper religious behavior in our patient [3]. Later stage consists of movement disorders (orolingual dyskinesia), autonomic instability (resulting in mechanical ventilation and coma) and catatonia. Brain MRI is often normal. EEG changes in the form of extreme delta brushes have been described in comatose patients, suggestive of prolonged clinical course [4]. Relation to ovarian teratoma in females demand a thorough evaluation for occult tumors. NMDA receptor encephalitis is responsive to immunotherapy (IVIG, Steroids, Plasma exchange and anti-CD20 antibody, Rituximab), if initiated early in its clinical course, and surgery as indicated for teratomas. We had previously reported a patient in minimally conscious state secondary to NMDA receptor, who after immunotherapy and tumor removal, had responded temporally to Zolpidem and would act appropriately as long as the medication lasts [3]. Based on the clinical experience, we had suggested use of Zolpidem as an adjunct to immunotherapy in patients with anti NMDA receptor encephalitis. This leads us to question the effect of Zolpidem in patients with disorders of consciousness.

Zolpidem is an non benzodiazepine imidazopyridine compound that selectively binds to alpha-1 subunit of GABA- $A$ receptor resulting in release of inhibitory neurotransmitter gamma amino butyric acid (GABA). Numerous case reports, case series, cohort studies, randomized placebo controlled studies have reported a wide range of response (no response to significant response) [4-9]. Beware of small sample size for these studies. A recent meta-analysis of 67 studies on use of
Zolpidem in neurological non-insomnia cases showed that only 11 studies had 10 or more patients. The study concludes a wide range of transient efficacy for Zolpidem in a wide range of neurological disorders especially movement disorders and disorders of consciousness. However, the data is limited by small sample size of individual studies [10].

Verdict-A case by case review is still required for the use of Zolpidem in patients with disorders of consciousness in general. In patients with NMDA encephalitis, Zolpidem may be a reasonable adjunct therapy after initial immunotherapy.

\section{References}

1. Gable MS, Sheriff H, Dalmau J, Tilley DH, Glaser CA (2012) The frequency of autoimmune $\mathrm{N}$-methyl-D-aspartate receptor encephalitis surpasses that of individual viral etiologies in young individuals enrolled in the California Encephalitis Project. Clin Infect Dis 54: 899-904.

2. Dalmau J, Tüzün E, Wu HY, Masjuan J, Rossi JE, et al. (2007) Paraneoplastic anti-N-methyl-D-aspartate receptor encephalitis associated with ovarian teratoma. Annals of Neurology 61: 25-36.

3. Appu M, Noetzel M (2014) Clinically significant response to zolpidem in disorders of consciousness secondary to anti-Nmethyl-D-aspartate receptor encephalitis in a teenager: a case report. Pediatric Neurology 50: 262-264.

4. Schmitt SE, Pargeon K, Frechette ES, Hirsch LJ, Dalmau J, et al. (2012) Extreme delta brush: a unique EEG pattern in adults with anti-NMDA receptor encephalitis. Neurology 79: 1094-1100.

5. Williams ST, Conte MM, Goldfine AM, Noirhomme Q, Gosseries O, et al. (2013) Common resting brain dynamics indicate a possible mechanism underlying zolpidem response in severe brain injury. Elife 2: e01157.

6. Whyte J, Myers R (2009) Incidence of clinically significant responses to zolpidem among patients with disorders of consciousness: a preliminary placebo controlled trial. Am J Phys Med Rehabil 88: 410-418.

7. Cohen SI, Duong TT (2008) Increased arousal in a patient with anoxic brain injury after administration of zolpidem. Am J Phys Med Rehabil 87: 229-231. 
8. Singh R, McDonald C, Dawson K, Lewis S, Pringle AM, et al. (2008) Zolpidem in a minimally conscious state Pentland. Brain Inj 22: 103-106.

9. Thonnard M, Gosseries O, Demertzi A, Lugo Z, Vanhaudenhuyse $A$, et al. (2013) Effects of Zolpidem on chronic disorders of consciousness: a prospective open label study. Functional Neurology 28: 259-264.

10. Bomalaski MN, Claflin ES, Townsend W, Peterson MD (2017) Zolpidem for the Treatment of Neurologic Disorders: A Systematic Review. JAMA Neurol 74: 1130-1139. 